\title{
PENERAPAN METODE DESAIN HIBRID BANGUNAN LAMA DAN BARU DALAM PERANCANGAN BANGUNAN EDU-REKREATIF KISARAN
}

\author{
William $^{1}$ \\ ${ }^{1}$ Program Studi S1 Arsitektur, Fakultas Teknik, Universitas Tarumanagara, william.nawei812@gmail.com
}

\begin{abstract}
Abstrak
Rutinitas keadaan perkotaan yang tidak sesuai dengan nilai kesejamanan millenial dalam hal rekreasi dan bersosialisasi menjadikan ketidak-seimbangan antara kota Kisaran dan generasi milenialnya. Generasi milenial merasa nilai kesejamanan di kota tidak berkembang. Oleh karena itu, solusinya adalah untuk menciptakan hubungan yang lebih positif antara aspek kota dan millenial. Dengan ini, Ruang Edu-rekreatif Kisaran didirikan dengan dibekali beberapa area massa yang masing-masing berfungsi untuk memenuhi sarana rekreatif dan edukatif yang tidak luput dari hal bersosialisasi. Bangunan dibentuk dengan metode hibrid dan sistem pemakaian kembali bangunan bekas rumah burung walet yang merupakan simbol jejak urban dan aspek kota. Dengan cara hibrid antara bangunan bekas dan bangunan baru dimana, bangunan bekas ditata ulang secara efektif agar dijadikan galeri dan area untuk bersosialisasi dengan kombinasi antara cahaya, material dan bentuk tipologi ruang berundak fleksibel sesuai karakter milenial. Bangunan baru yang berasal dari kombinasi kontekstual tapak yaitu elemen ekologis sekitar tapak dan kota didesain berbasis tipologi sirkulasi, mengingat sirkulasi merupakan salah satu aspek penting dalam memaksimalkan pengalaman yang rekreatif edukatif dan menghasilkan program seperti area konservasi ekologis, galeri dan area rekreatif lainnya dimana design akhir bangunan disuntikan lokalitas tema yaitu morfologi sarang walet itu sendiri. Kombinasi antara bentuk massa dan program yang kontekstual menghasilkan suatu bangunan dengan konsep yang berbeda namun harmonis agar secara positif dan simbolis mengubah pandangan kota saat ini.
\end{abstract}

Kata kunci: Adaptif; Edu-Rekreatif; Hibrid; Kontekstual; Milenial

\begin{abstract}
The urban routine which is not in accordance with the value of millennials in terms of recreation and socialization makes the imbalance between the city of Kisaran and its millennial generation. Millennials feel that the value in the city barely develop. Therefore, the solution is created more positive relationship between the aspects of the city and millennials. According to the issue, the Edu-Recreative Space will be established with numbers of mass areas respectively while functioning to fulfill recreational and educational facilities that are not free from socializing. The building will be formed by Hybrid method and Adaptive Re-used of the former building of swallow's house which is a symbol of the urban trail and aspects of the city. By Hybrid method, between used buildings and new buildings where, used buildings are rearranged effectively so that they become galleries and areas for socializing with a combination of light, material and flexible space typology forms likely according to millennial characters. While, new buildings derived from a combination of contextual sites, namely ecological elements around the site and the city will be designed based on circulation typologies, given that circulation is an important aspect in maximizing educational recreational experiences and producing programs such as ecological conservation areas, galleries and other recreational areas, where the final design of the buildings which will be injected locality theme, by the morphology of the swallow nest itself. The combination of mass forms and contextual programs produces a building with a different but harmonious concept to positively and symbolically change the current perspective of the city.
\end{abstract}

Keywords: Adaptive; Edu-Recreative; Hybrid; Contextual; Milenial 


\section{PENDAHULUAN}

Kisaran merupakan kota yang berlokasi pada kabupaten Asahan, Sumatera Utara. Kotamadya Kisaran memiliki dua kecamatan yaitu Kisaran Barat dan Kisaran Timur. Dimana kecamatan Kisaran Barat dan Timur masing-masing merupakan daerah yang terletak pada pinggiran kota (sekitar 3-4 jam perjalanan dengan mobil dari kota Medan) dengan kepadatan penduduk dan perkembangan ekonomi menengah. Tetapi seiring berkembangnya zaman, kota ini tidak mengalami perubahan dan tidak terlihat kehadiran area dan bangunan dengan inovasi-inovasi yang sesuai dengan perkembangan zaman kini, baik secara fisik maupun fungsi yang hingga sekarang masih menunjukkan kurangnya area untuk bersosialisasi dan berekspresi terutama untuk generasi milenial. Pemakaian fungsi lahan untuk sektor perdagangan dan perkebunan merupakan salah satu faktor utama kurangnya area inovatif di Kisaran ditambah dengan banyaknya bangunan bekas peternak walet yang terlantar dan tidak digunakan secara efektif semakin menambah kombinasi buruk antara lingkungan kota dengan pemakainya.

Globalisasi dan perkembangan teknologi ini menghasilkan suatu karakter milenials yaitu: kreatif, ekspresif serta tidak suka hal monoton, dan terutama interaksi sosial merupakan moto utama generasi ini. Karakter kota yang tidak supportif dengan karakter milenial memunculkan sifat travelling milenial dimana karakter ini berkembang karena tidak terdapatnya hal baru didalam kota yakni milenial cenderung menjauh dan mengeksplorasi tempat yang berbeda.Dalam mengubah pandangan aspek kota terhadap keseimbangan nilai kesejamanan millenial maka Kisaran edu-recreative space merupakan jawaban untuk permasalahan diatas dimana dihadirkan dengan basis program dan bangunan yang kontekstual, ekologis dan berkelanjutan sehingga menciptakan dampak positif dalam kehidupan kota dan millenial .

\section{KAJIAN LITERATUR}

Milenial Di Indonesia

Menurut Ali, Hasanuddin dari artikel "Generasi Millennial Indonesia: Tantangan dan Peluang Pemuda Indonesia", milenial di Indonesia adalah 50\% dari penduduk usia produktif dan sering kali disebut sebagai bonus demografi yang akan memberikan potensi besar bagi perekonomian Indonesia. Alvara Research Center mencoba memprediksi wajah Indonesia 2020. Wajah Indonesia 2020 setidaknya bisa kita lihat dari berbagai fenomena-fenomena yang bibitnya sudah terjadi saat ini. Paling tidak ada tiga fenomena yang bisa menjelaskan wajah Indonesia di tahun 2020 yaitu pergeseran Komposisi Urban-Rural, Penduduk kelas menengah, dan Komposisi penduduk muda: Kehidupan sosial dan budaya

Dalam masyarakat urban, status sosial adalah sesuatu yang penting. Alvara Research Center menyatakan pencapaian karir yang disimbolkan oleh rumah dan mobil yang memadahi kedepan akan menjadi simbol status sosial di masyarakat. Karir yang sukses akan meningkatkan status dimata masyarakat dan fenomena ini bisa anda amati dimasyarakat sekitar kita.

Budaya lain yang muncul adalah budaya selfie dan narsis. Berkembangnya teknologi kamera smartphone salah satunya mendorong munculnya fenomena selfie dan narsis. Selfie dan narsis bukan lagi fenomena tetapi kedepan akan menjadi suatu budaya. Setelah berselfie dan bernarsis ria, mereka langsung mengunggah ke sosial media. Tempat-tempat menarik menjadi spot selfie dan narsis secara tidak langsung memunculkan fenomena sosial lain, yaitu membludaknya pengunjung tempat wisata.

\section{Pengertian Arsitektur yang Rekreatif dan Edukatif}

Menurut jurnal Deviana mengenai "Taman Rekreasi Edukatif Anak di Kota Makassar" (Zuastika, 2010: 13) arsitektur memiliki pengertian sebagai : Ilmu yang mempelajari tentang lingkungan binaan, yang diperuntukkan bagi manusia sebagai penggunanya. Rekreatif merupakan kata sifat yang berasal dari kata dasar rekreasi yang bersifat dapat mengekspresikan dan menjelaskan aktifitas yang dilakukan pada waktu senggang. Hal ini dapat dilakukan untuk membentuk, meningkatkan kembali kesegaran fisik, mental, pikiran dan daya kreasi secara 
individu maupun kelompok, yang hilang akibat rutinitas sehari-hari dengan jalan mencari kesenangan, hiburan dan kesibukan yang berbeda yang dapat memberikan kepuasan dan kegembiraan yang akhirnya ditujukan bagi kepuasan lahir dan batin. Edukatif merupakan kata sifat yang berasal dari kata dasar edukasi yang memiliki arti bersifat mendidik. Dengan kata lain kegiatan yang memberikan kegiatan yang mencerdaskan dan menambah wawasan pengetahuan. Jadi, dapat disimpulkan bahwa arsitektur rekreatif edukatif adalah konsep merancang suatu bangunan yang bersifat memberi penyegaran kembali baik jasmani dan rohani seseorang, sekaligus dapat memberikan pembelajaran dan pemahaman yang mencerdaskan dan menambah wawasan pengetahuan.

Jenis- jenis kegiatan yang bersifat edukatif - rekreatif diantaranya :

- Big muscle activities: rekreasi yang memerlukan tenaga atau fisik.

- Social activities: rekreasi yang bertujuan sosial, seperti: bercakap-cakap, jalan-jalan bersama, melibatkan interaksi sosial sebagi kegiatan utama.

- Physical recreation: memerlukan usaha atau kegiatan fisik sebagai kegiatan utama. d) Cognitive recreation: melibatkan kebudayaan, pendidikan, dan kreatifitas.

- Environment-related recreation: rekreasi yang memanfaatkan potensi alam dalam kegiatannya, seperti olahraga arung jeram.

- Rhythms and music: rekreasi yang diakibatkan oleh irama dan musik yang memberikan kesenangan, persahabatan, seperti bernyanyi dan berdansa.

- Nature learning: rekreasi di alam terbuka (berkemah dan mendaki gunung).

- Relaxation: rekreasi yang bertujuan melepaskan diri dari ketegangan dan kelelahan mental dan fisik untuk mencapai kesenangan dan kesegaran, misalnya; menikmati pemandangan alam, duduk di taman, dan lain-lain.

\section{Arsitektur hibrid}

Arsitektur hibrid adalah penyatuan beberapa aspek dalam ruang lingkup arsitektural. Menurut buku Ikhwanuddin " Menggali Pemikiran Postmodernism dalam Arsitektur "Penekanan pengertian hybrid ini adalah "hasil" dari persilangan atau penggabungan. (Febriana D.S. Rompis dan Sangkertadi: 2011) Menurut Jencks, hybrid merupakan suatu metode untuk menciptakan sesuatu dengan pola-pola lama (sejarah), namun dengan bahan dan teknik yang baru. (Jencks, C. :1997) Dengan kata lain menggabungkan bentuk-bentuk arsitektur dulu dengan hal baru sesuai konteks kesejamanan. Metode hybrid dinyatakan melalui tahapan-tahapan quatation, manipulasi elemen, dan unifikasi dan penggabungan.

\section{Arsitektur kontekstual}

Didalam jurnal Widati Titiani dengan judul Pendekatan Kontekstual dalam Arsitektur Frank Lloyd Wright Menurut Wolford (2004), Kontekstual dalam arsitektur umumnya digunakan untuk mengartikan kontinuitas dan hubungan antara suatu bangunan dengan sekitarnya. Kata "konteks" adalah dari bahasa latin yaitu textus, yang berarti "kain (bahan)", textere yang berarti "menjahit (menyatukan)", dan con yang berarti "dengan", Kata latin contextus berarti sebuah kain yang dijahit (bahan yang disatukan).

Menurut" Jormakka, Kari. "Basic Design Methods" Dalam arsitektur, konteks melibatkan hubungan khusus suatu bangunan dengan lingkungannya, sebagaimana hubungan antara bangunan dengan tapaknya (site), yang dapat terlihat dari bentuk fisiknya dan bentuk morfologinya. Dalam arti yang lebih luas, konteks dapat juga berarti bagian dari suatu lokasi, baik lokasi yang terletak di daerah perkotaan atau di daerah pedesaan.

\section{Pemanfaatan Adaptif (Adaptive Reuse)}

Menurut artikel Selenia, dkk (2015) berjudul Adaptive Reuse pada PT. Cipta Niaga di Kawasan Kota Tua Jakarta, Pemanfaatan adaptif (Adaptive reuse) adalah suatu cara atau metode dimana dilakukan perubahan terhadap bangunan sehingga dapat mengakomodasi kebutuhan baru dan adaptasi yang dilakukan mampu menambah nilai dan kualitas bangunan bersejarah. 


\section{METODE}

Data awal yang dikumpulkan dimulai dari penentuan lokasi terbaik tapak yang sesuai dengan kriteria terletak ditengah-tengah kota dan kaya akan nilai ekologis, lalu terdapat simbol jejak urban perkotaan yaitu rumah burung walet yang sudah terbengkalai.

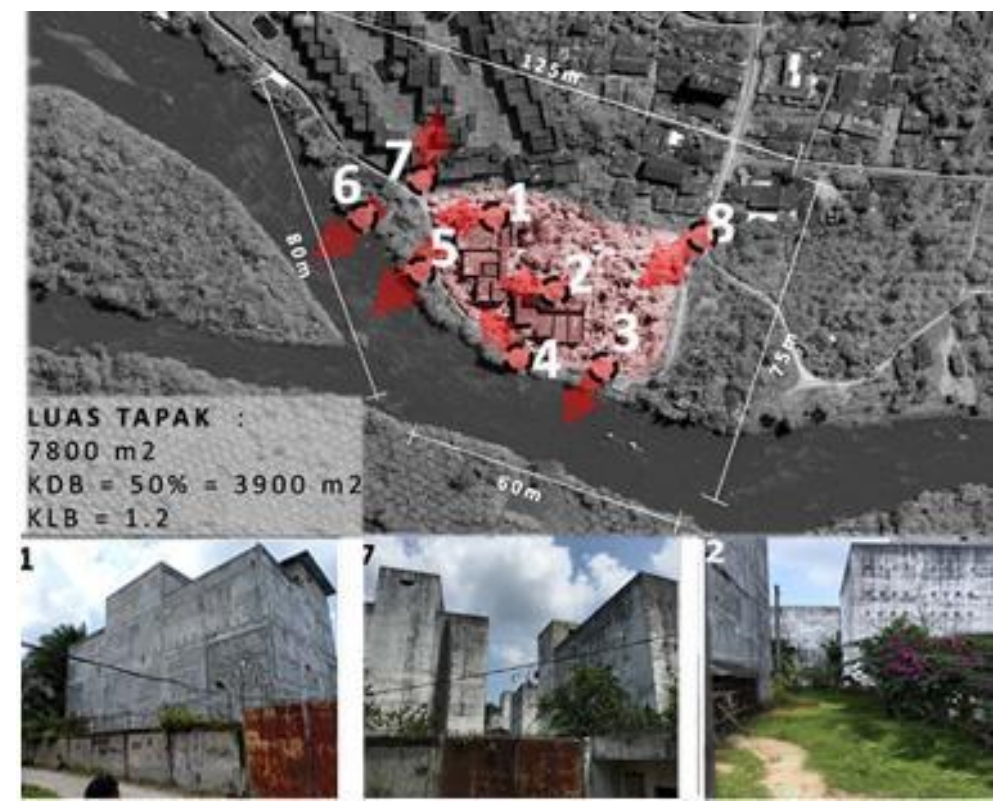

Gambar 1. Data Survey Tapak

Sumber: Penulis, 2019

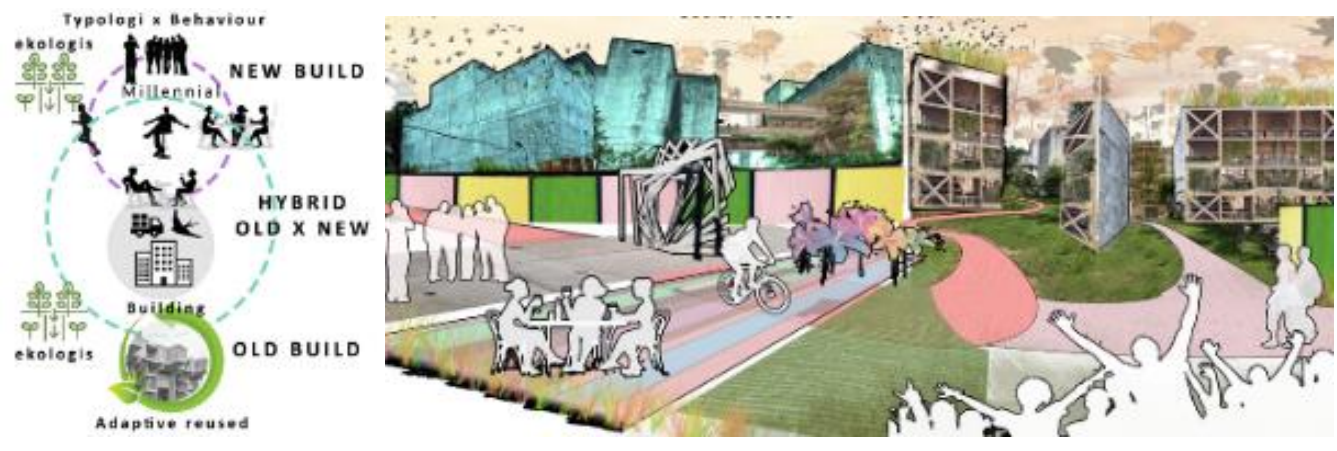

Gambar 2. Konsep Proyek

Sumber: Penulis, 2019

Setelah pemilihan tapak, dilakukan penentuan konsep atau metode perancangan yang sesuai terhadap isu yang ada yaitu dengan memakai metode hibrid antara bangunan baru dan bangunan lama dimana didukung strategi design adaptive reuse dalam pengolahan bangunan lama lalu dikombinasi dengan bangunan baru yang bentukannya didukung dari dialog between typology and behaviour, dimana behaviour berasal dari program apa yang dibutuhkan millenial.

Pengumpulan potensi-potensi sumber daya secara kontekstual yang dapat dimanfaatkan secara positif, yang berasal dari data dan survey lapangan yang dimana akan dikombinasi sesuai dengan aspek yang dibutuhkan oleh generasi millenial. Hasil dari survey kuesioner dan wawancara langsung yang didukung dengan teori yang sesuai terhadap kombinasi hasil analisis menunjukan program bangunan yang sesuai bersifat rekreatif - edukatif sekaligus sebagai area bersosialisasi. 
Tabel 1. Tabel Studi Tipologi Program

\begin{tabular}{|c|c|c|c|}
\hline $\begin{array}{l}\text { Potensi millenial } \\
\& \text { kota }\end{array}$ & $\begin{array}{l}\text { Aktivitas } \\
\text { rekreasi- } \\
\text { edukasi }\end{array}$ & Program & Sifat program \\
\hline $\begin{array}{l}\text { Kurangnya area } \\
\text { bersosialisasi } \\
\text { (yang tren) }\end{array}$ & $\begin{array}{l}\text { social } \\
\text { activities/ } \\
\text { music rhytm }\end{array}$ & $\begin{array}{l}\text { - Food corner ( music, food) } \\
\text {-community space(social stairs, pocket } \\
\text { park) }\end{array}$ & $\begin{array}{l}\text { Rekreasi (sosialisasi, ekspresif) } \\
\text { Rekreasi (sosialisasi) }\end{array}$ \\
\hline $\begin{array}{l}\text { Pemanfatan } \\
\text { Potensi SDA }\end{array}$ & $\begin{array}{l}\text { environment } \\
\text { recreation }\end{array}$ & $\begin{array}{l}\text { - Ecological park } \\
\text { (wetland, botanic plantation) } \\
\text { - Bird park } \\
\text { - Galeri walet }\end{array}$ & $\begin{array}{l}\text { Rekreasi (ekspresif), edukasi } \\
\text { Rekreasi (ekspresif), edukasi } \\
\text { Rekreasi (ekspresif), edukasi }\end{array}$ \\
\hline $\begin{array}{l}\text { Regiatan yang } \\
\text { (olahraga) }\end{array}$ & $\begin{array}{l}\text { physical } \\
\text { recreation }\end{array}$ & $\begin{array}{l}\text { - Rekreatif sport (jogging) } \\
\text { - Fleksibel sport (outbond track) }\end{array}$ & $\begin{array}{l}\text { Rekreasi (ekspresif), kesehatan } \\
\text { Rekreasi (ekspresif) }\end{array}$ \\
\hline $\begin{array}{l}\text { Menciptakan } \\
\text { program yang } \\
\text { lebih rekreatif } \& \\
\text { edukatif, trendier } \\
\text { (ekspresif) }\end{array}$ & $\begin{array}{l}\text { creative } \\
\text { play/hand } \\
\text { intellect }\end{array}$ & $\begin{array}{l}\text { - Birdnest processing product } \\
\text { - Workshop }\end{array}$ & $\begin{array}{l}\text { Edukasi, sosialisasi } \\
\text { Edukasi }\end{array}$ \\
\hline
\end{tabular}

Strategi design adaptive reused mempunyai 2 massing utama old $x$ new building, masing" bangunan mempunyai program pusat :

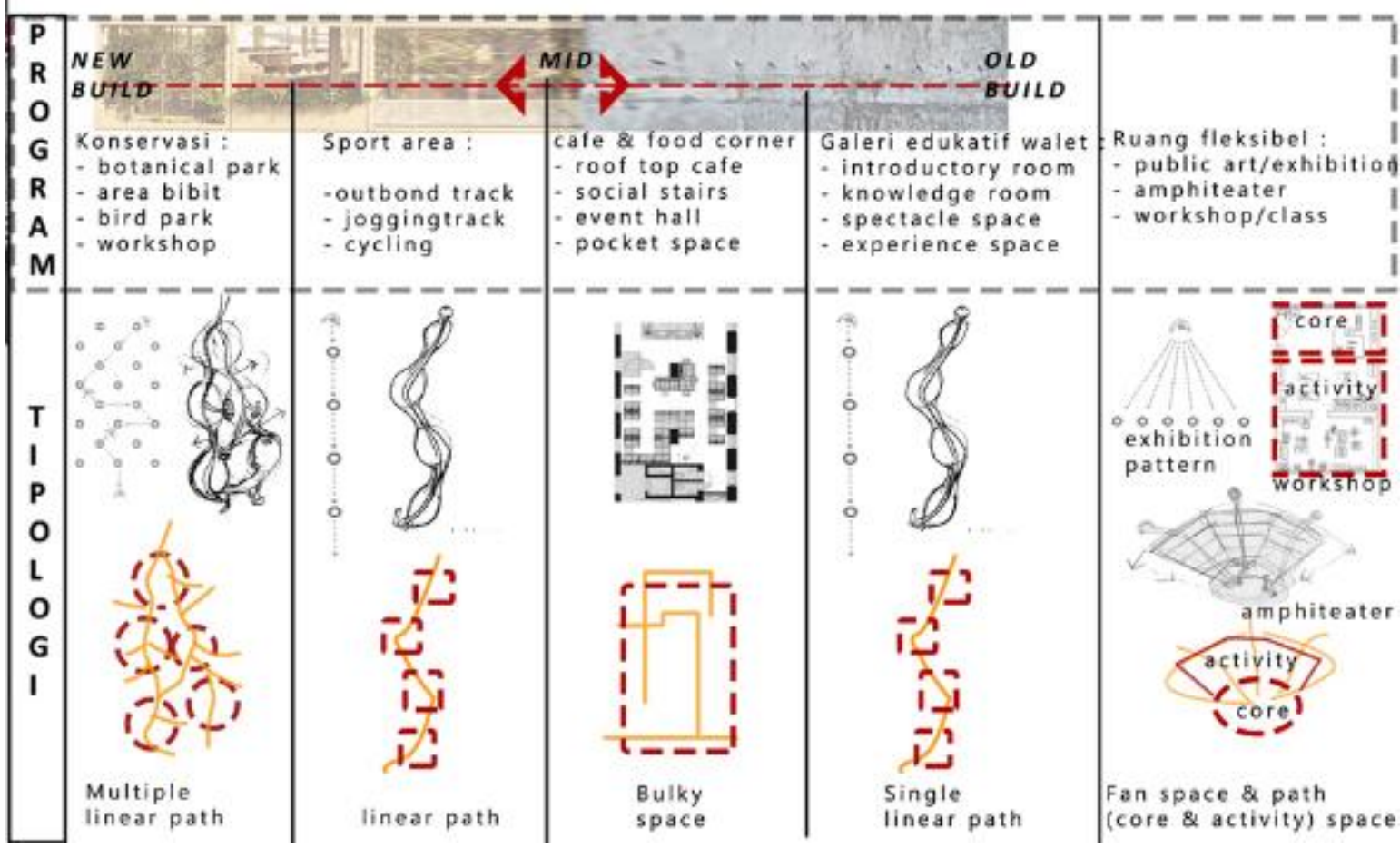

Sumber: Penulis, 2019

Program yang ditentukan nantinya akan distudi untuk menghasilkan bentuk dasar tipologi yang akan terdapat didalam bangunan, tipologi tersebut berbasis hubungan pergerakan sirkulasi terhadap ruang yang dihasilkan. Nantinya akan menghasilkan letak program yang sesuai dengan pembagian zoning program yaitu area bangunan baru dan area bangunan lama.

Setelah program dan tipologi ditentukan maka menghasilkan beberapa gambaran yang dapat diterapkan kedalam program proyek Kisaran edu-recreative space zoning program secara makro yaitu : ecological program, sport recreation, food corner, dan swallow gallery. 

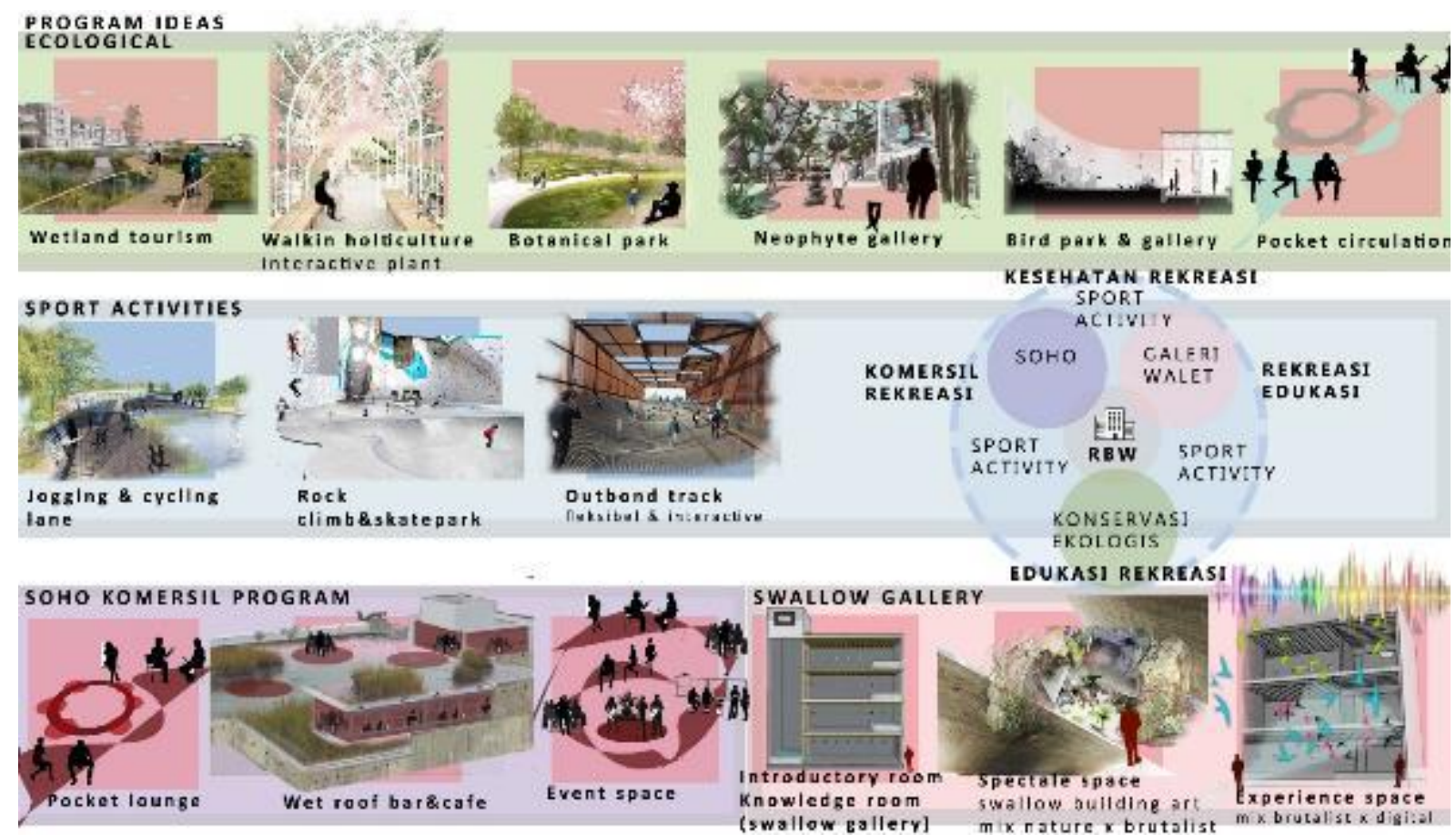

Gambar 3. Diagram Program Arsitektur

Sumber: Penulis, 2019

\section{DISKUSI DAN HASIL}

Kisaran edu-recreative space berlokasi di Kisaran, Sumatra Utara berada di tengah pusat kota dan natural elemen kota. Proyek ini terdiri fungsi - fungsi sebagai berikut; lobby, bird park bird gallery, agriculture gallery, uv storage, botanical park, miniforest, pocket park, social stairs, event space, food corner, restaurant, wet cafe, swallow gallery, wetland tourism. Keseluruhan bangunan dengan luas $7856 \mathrm{~m}^{2}$ dimanfaatkan 40 persen sebagai area hijau (ekologis) bangunan dimana bangunan dapat menampung \pm 400 orang dengan maksimal daya tampung \pm 700 orang, orientasi kendaraan yang diutamakan adalah kendaraan bermotor, didukung dengan parkiran mobil dan bus juga area tapak yang terletak diujung dari jalan padat kendaraan menciptakan area yang ramah terhadap pejalan kaki.
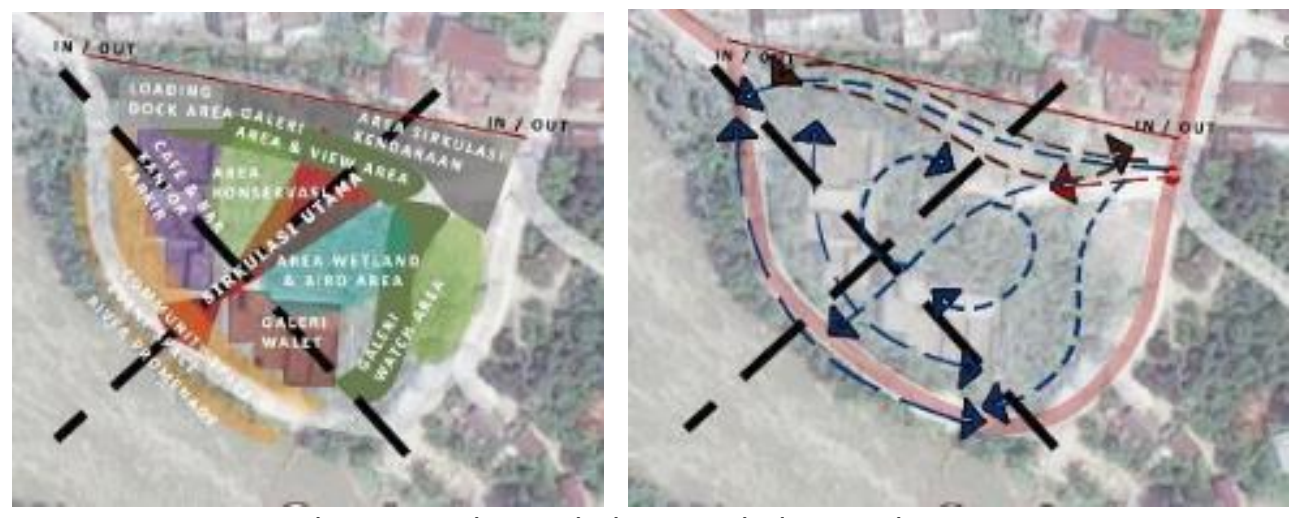

Gambar 4. Analisis sirkulasi tapak dan Analisis zoning

Sumber: Penulis, 2019 
Secara garis besar kedua hasil analisis diatas merupakan dasar perletakan dan pembentukan massa bangunan yang kontekstual tapak. Denah Kisaran edu-recreative space mempunyai pembagian massa sesuai konteks tapak dimana area yang mengarah kesungai dijadikan area community space atau area yang difugnsikan sebagai tempat keramaian, sementara untuk area yang orientasinya mengarah ke pusat kota dijadikan area utama program rekreatif edukatif.

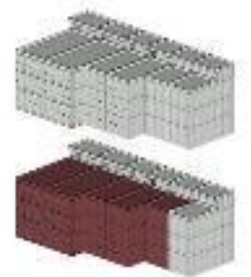

Bangunan eksistong sebazian bekas bangunan. RBW di hilangkan terutama dibazian fasad untuk menghilangkan kesan massive

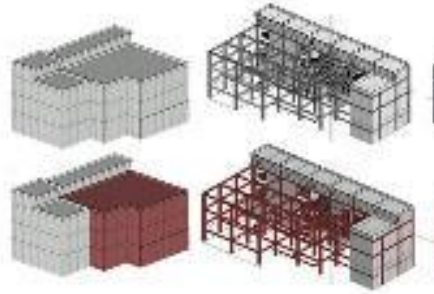

menyisakan sebagian struktur dasar darl beatuk tipologl dan geometri baneunan
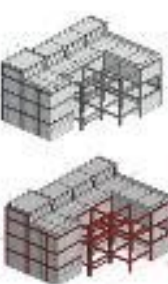
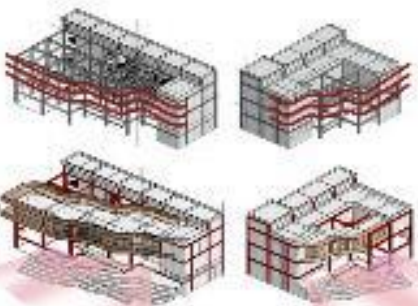

struktur dikombinasi dengan new build - berbentuk hubrig porasit terhadap pow - hasil proyeksi fisik menyisakan ruang terbuka yang fleksibal

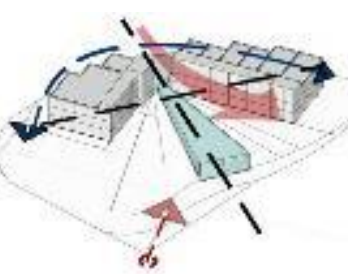

Lksistine aksis

massa baru akan menjodi cere sirkulosi yane menehubangsan tap proeram

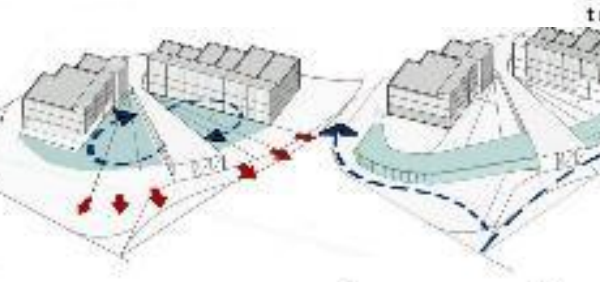

Insertion

mpnjadi ruang pusiti

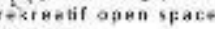
pragram
Massa mercsoon palur irkulasl tapak dimana ungsi mossa mengarah ka komers or ented

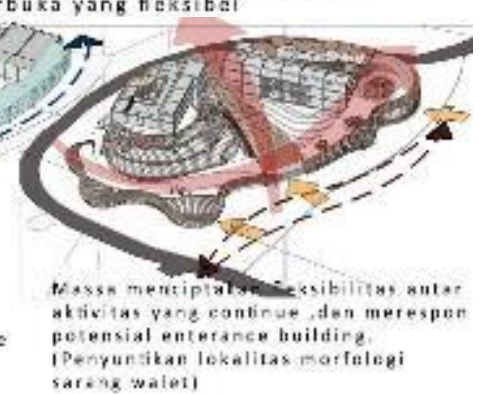

Gambar 5. Skema Desain Bangunan Lama dan Baru Sumber: Penulis, 2019

Massa baru bangunan juga dibentuk dalam skala humanis dan diberi sentuhan rekreatif, bangunan dibuat lebih exploratif dengan atap bangunan dibentuk sebagai ram dan difungsikan sebagai area jogging dan area sirkulasi vertikal antar lantai dimana ini merespon fleksibilitas serta kontinuitas antar aktivitas di dalam bangunan.

Berikut merupakan gambaran mengenai ruang-ruang yang terbentuk dari program dalam menciptakan area rekreatif - edukatif :

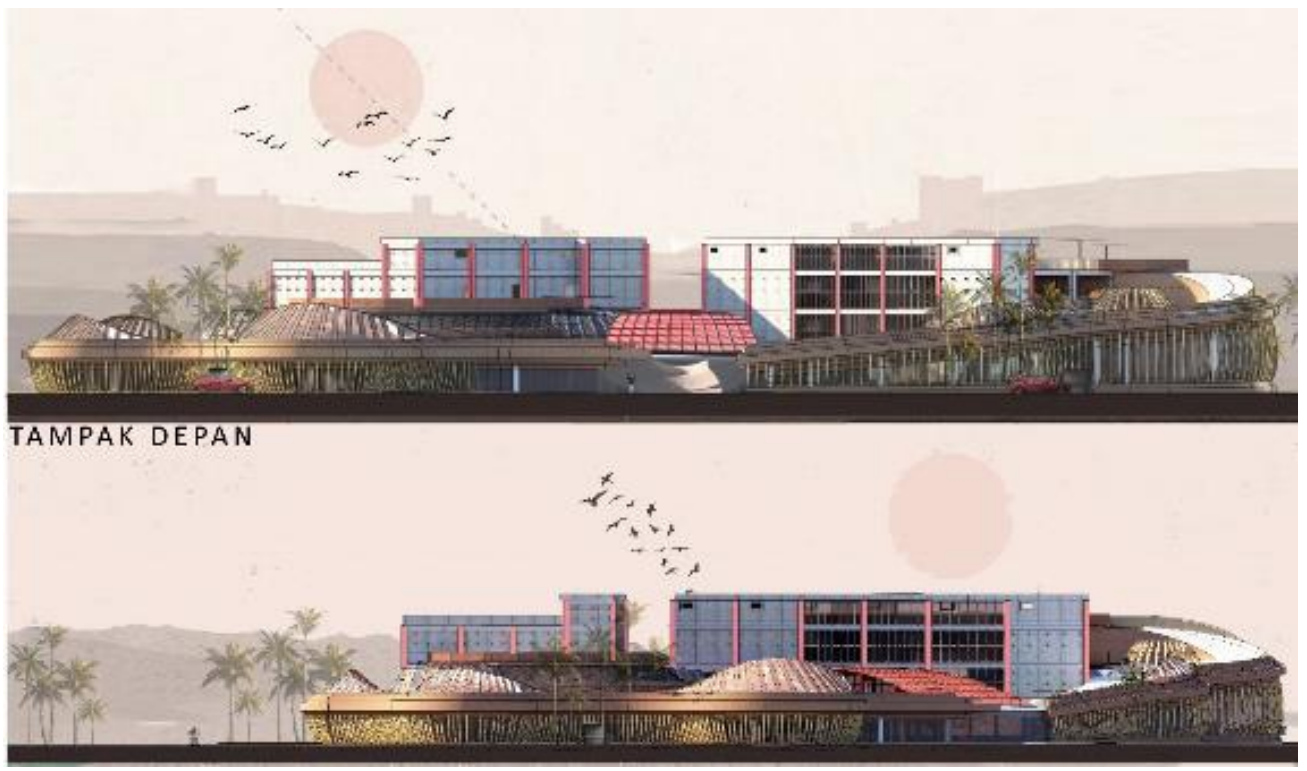

Gambar 6 . Tampak

Sumber: Penulis, 2019 


\section{Eksterior}

Konsep perbaharuan pemilihan material pada bangunan berdasarkan konsep yaitu adaptif dan kontekstual dimana untuk material adaptif mayoritas memakai material dingin yaitu konkret sementara untuk lebih kontekstual maka memakai material hangat yaitu kayu yang menciptakan konsep hybrid old and new terhadap material building.

Konsep pemakaian material pada eksterior bangunan merupakan kombinasi antara 2 elemen yaitu elemen bangunan lama yang mayoritas terdiri dari material beton dan area bangunan baru yang mayoritas material terdiri dari kayu dan kaca.

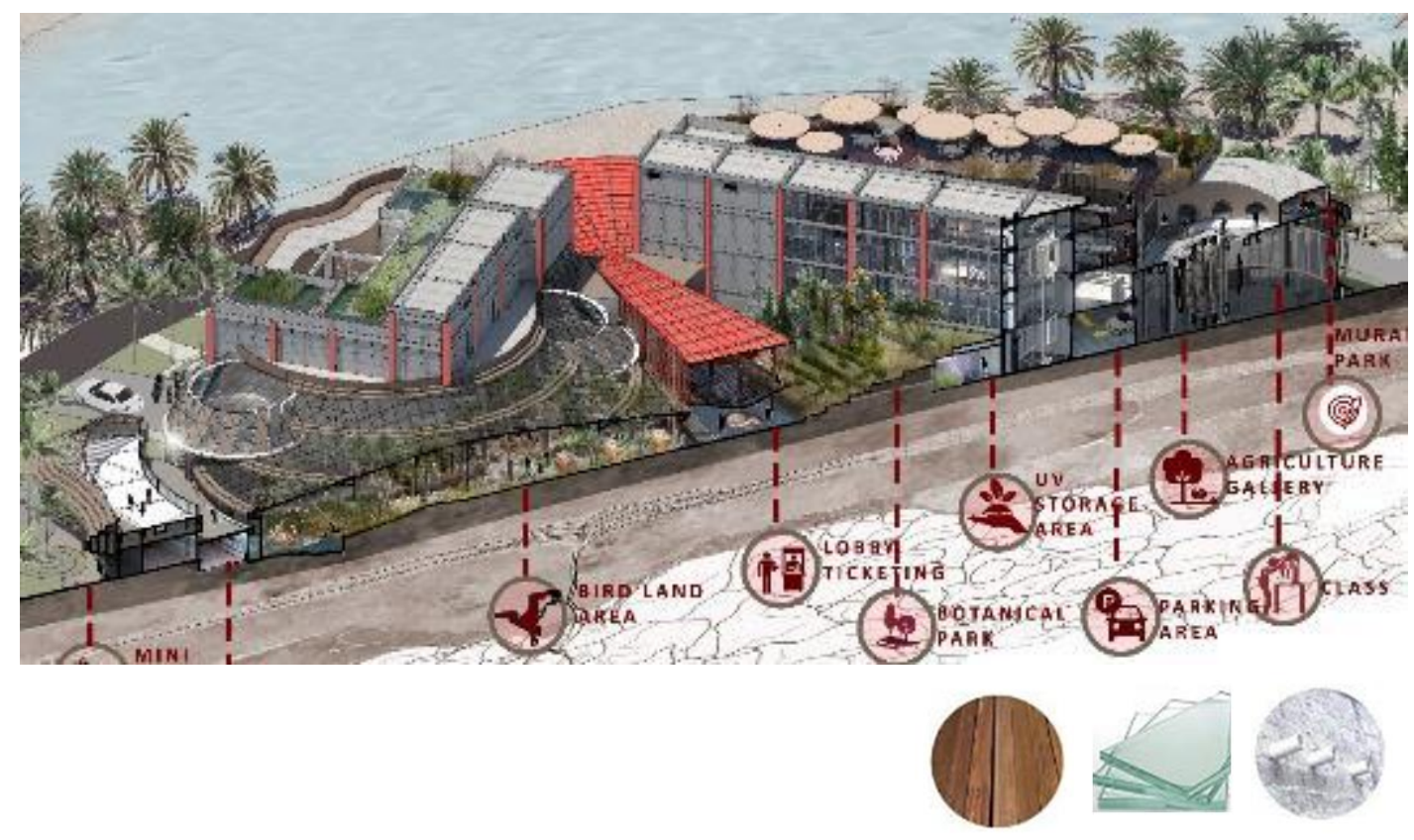

Gambar 7. Potongan Axonometri

Sumber: Penulis, 2019

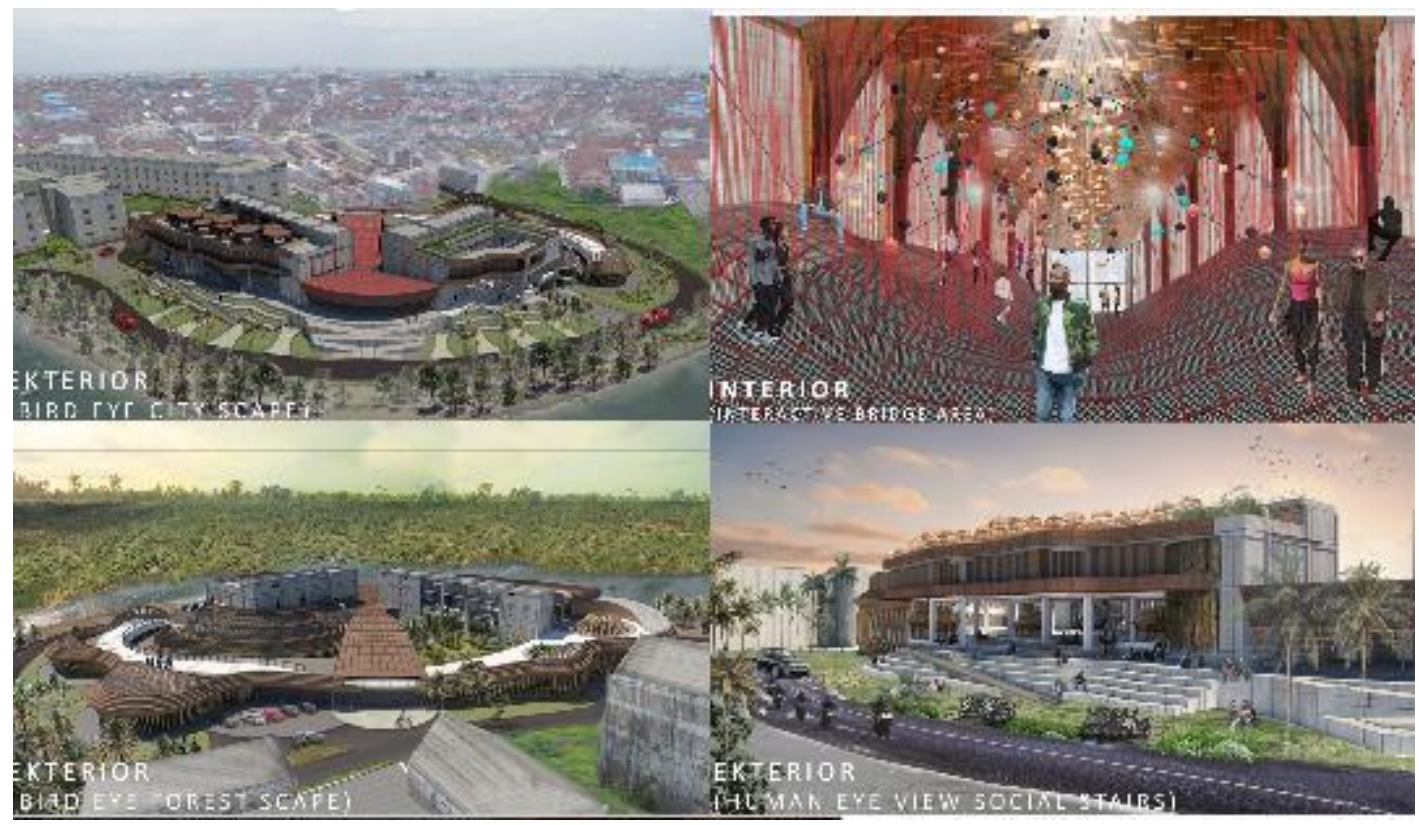

Gambar 8 . Eksterior dan Interior

Sumber: Penulis, 2019 


\section{Interior}

Untuk area interior bangunan lama sebagian material dipertahankan dimana mayoritas memakai material konkret adapun area yang lebih jelas dengan perubahan fungsi yang memepengaruhi bentuk bukaan terhadap pencahayaan yaitu pada area ternak walet yang dikelola menjadi galeri walet yang menampilkan keaneka ragaman pengetahuan, suasana, dan kondisi rumah burung walet yang disuntikan dengan cara audio- visual -digital.
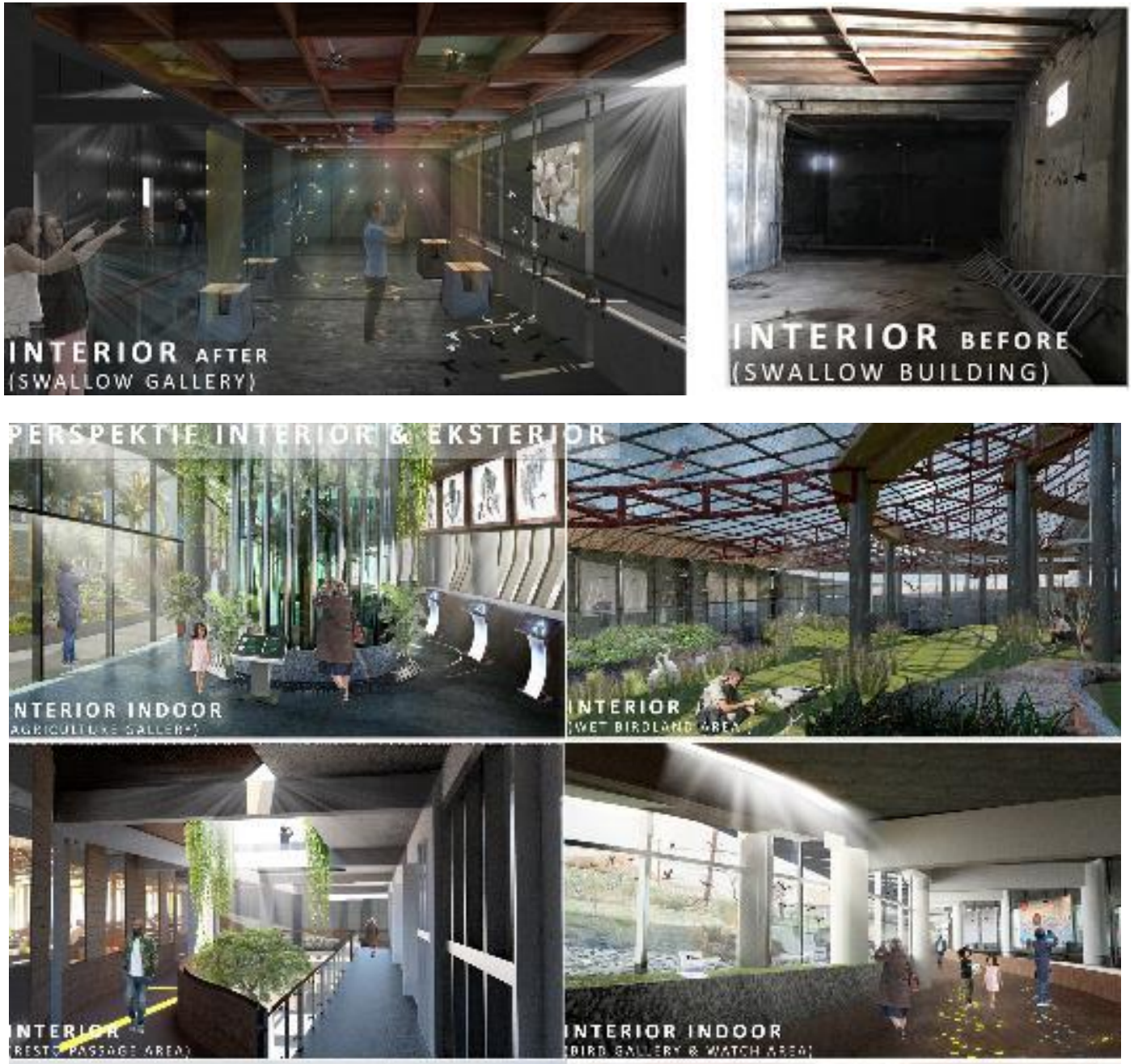

Gambar 9. Interior Galeri Walet

Sumber: Penulis, 2019

Area interior bangunan baru bagian galeri memakai kombinasi material kayu dan batu alam sementara interior area restoran terdapat perbaduan hibrid material kayu dan beton dimana pada area ini merupakan salah satu hibrid antara area bangunan lama dan bangunan baru.

\section{KESIMPULAN DAN SARAN}

Kisaran Edu-Recreative Space berperan sebagai area rekreatif dan edukatif juga sebagai penampung area bersosialisasi dimana dengan memanfaatkan strategi design adaptive reuse dan memakai metode perancangan hibrid dan kontekstual juga secara simbolis bangunan berfungsi sebagai pelopor perubahan terhadap perspektif didalam kehidupan perkotaan Kisaran.

Saran mengenai penelitian yang mungkin dapat dikembangkan adalah pada metode perancangan adaptive reuse terhadap tipologi bangunan rumah burung walet dan pada pergerakan studi karakter millenial dikota berkembang. 


\section{REFERENSI}

Ali, H. (2018). Generasi Millennial Indonesia: Tantangan dan Peluang Pemuda Indonesia, diakses pada 14 Januari 2019, http://alvara-strategic.com/generasi-millennial-indonesia-tantangandan-peluang-pemuda-indonesia/

Deviana. Jurnal. (2017). "Taman Rekreasi Edukatif Anak di Kota Makassar" diakses Januari 2017

Ikhwanuddin. (2018). "Menggali Pemikiran Posmodernism Dalam Arsitektur" Gajah Mad University Press

Jormakka, K. (2007). "Basic Design Methods" Birkhäuser Architecture

Selenia, N., dkk. (2015). Adaptive Reuse pada PT. Cipta Niaga di Kawasan Kota Tua Jakarta, diakses pada 18 Januari2019,https://library.binus.ac.id/eColls/eThesisdoc/Bab2/2014-2-01239AR\%20Bab2001.pdf

Widati, T. (2015). Pendekatan Kontekstual dalam Arsitektur Frank Lloyd Wright, diakses pada 17 Januari 2019, http://e-journal.upr.ac.id/index.php/Pra/article/view/373/327 